http://revped.ise.ro

Print ISSN 0034-8678; Online ISSN: 2559 - 639X

\title{
DEVELOPING SOCIAL INCLUSION AND 21ST \\ CENTURY SKILLS THROUGH PROJECT BASED \\ LEARNING IN THE ERASMUS + PROJECT "WISH"
}

DEZVOLTAREA INCLUZIUNII SOCIALE ȘI A COMPETENȚELOR SECOLULUI XXI PRIN ÎNVĂȚAREA BAZATĂ PE PROIECTE ÎN CONTEXTUL PROIECTULUI ERASMUS + „WISH”

\section{Darius BOROVIC}

\author{
Journal of Pedagogy, 2019 (2), 29 - 46 \\ https://doi.org/10.26755/RevPed/2019.2/29
}

The online version of this article can be found at: http://revped.ise.ro/category/2019-en/

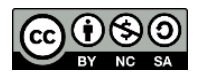

This work is licensed under the Creative Commons Attribution-NonCommercial-ShareAlike 4.0 International License. To view a copy of this license, visit http://creativecommons.org/licenses/by-nc-sa/4.0/ or send a letter to Creative Commons, PO Box 1866, Mountain View, CA 94042, USA.

Published by:

\section{INSTITUTUL DE ȘTIINȚE ALE EDUCAȚIEI}

http://www.ise.ro/

Further information about Revista de Pedagogie - Journal of Pedagogy can be found at:

Editorial Policy: http://revped.ise.ro/editorial-policy/ Author Guidelines: http://revped.ise.ro/the-writer-guide-2/ 


\title{
DEVELOPING SOCIAL INCLUSION AND $21^{\mathrm{ST}}$ CENTURY SKILLS THROUGH PROJECT BASED LEARNING IN THE ERASMUS + PROJECT "WISH"
}

\section{Darius Borovic*}

\author{
West University of Timişoara, \\ Teacher Training Department, \\ Timişoara, Romania \\ darius.borovic@e-uvt.ro
}

\begin{abstract}
The study presents the findings of an experimental research related to the implementation of Project Based Learning in the Erasmus Plus KA201 project Work for an Inclusive School Heritage in Romanian high-schools. One of the projects goals was to develop, to apply and to exchange innovative practices in the 5 countries of the Erasmus partnership (Slovakia, Turkey, Catalonia - Spain, Italy and Romania). The experimental research studied an original Project Based Learning strategy developed from John Dewey's ideas, Project Citizen and the MAPA methodology for planning funding projects. Teachers from the 5 partner countries were trained and the students from the participant high-schools planned and implemented several social action projects. In Romania we surveyed a sample of 226 students using a validated questionnaire with the majority of questions taken from international literature. The quasi-experimental research proves a statistically significant increase of the students' positive attitudes toward migrants and minorities, several institutions, civic action, and social inclusion. The desire to participate in solving problems of the community and the level of development of several $21^{\text {st }}$ Century Skills have also improved.
\end{abstract}

Keywords: Project Based Learning, social inclusion, $21^{\text {st }}$ Century Skills.

* Associate Professor, PhD., West University of Timişoara, Teacher Training Department, Timişoara, Romania. 


\section{Rezumat}

Studiul prezintă rezultatele cercetării experimentale ale aplicării metodologiei Project Based Learning în cadrul proiectului Erasmus Plus KA201 Work for an Inclusive School Heritage, în licee din Romania. S-a vizat dezvoltarea, schimbul şi transferul de practici inovatoare între cele 5 ări ale parteneriatului ERASMUS + (Slovacia, Turcia, Catalonia - Spania, Italia şi România). Drept metodologie experimentală s-a utilizat o variantă originală de Project Based Learning bazată pe ideile lui John Dewey, abordarea Project Citizen şi metodologia de planificare a proiectelor de finan are MAPA. Profesori din cele 5 ări partenere au participat la cursuri de formare, iar elevii din liceele implicate au planificat şi implementat diferite proiecte de ac iune socială. În cadrul studiului s-au evaluat atitudinile unui eşantion de 226 de elevi din România pe baza unui chestionar validat, preluat par ial din literatura de specialitate. Cercetarea quasi-experimentală dovedeşte o creştere semnificativă statistic a atitudinilor pozitive fa ă de migran $i$ şi minorită $i$, fa ă de anumite institu ii, ac iuni civice, incluziune socială. S-a îmbunătă it, de asemenea, dorin a de participare în solu ionarea unor probleme ale comunită ii şi nivelul de dezvoltare a unor competen e necesare pentru secolul XXI.

Cuvinte-cheie: competen e pentru sec. XXI, incluziune socială, învă are prin metoda proiectului.

\section{Project Based Learning - WISH PBL}

The original teaching and learning method used in the WISH project and proposed by the author (Borovic, 2019), as well as in the related experimental research is based on John Dewey's work, Project Citizen developed by the Center for Civic Education and the MAPA methodology for planning projects (Schiefer \& Döbel, 2001).

WISH PBL is a student-centered method with an emphasis on real world problems and the students' activity to plan and implement a solution to these problems. After observing the surrounding world, talking to people, seeking information and group deliberation (based on critical thinking), the student team chooses one main problem which will help them set the project goal. The teacher may facilitate this process and help students formulate the problems correctly, but the main problem is chosen and formulated by the student team. The project can be based on the participation of the class as a whole or of smaller groups of students. During the implementation of 
WHISH PBL the students in Romania and the other countries developed small group projects (5-12 students) and large group projects (15-25 students, all students from one class).

The next steps of WHISH PBL are inspired from the MAPA methodology: the students brainstorm for additional problems related to the main one. With teacher facilitation they will organize these problems in problem trees. The problem "trees" are only a graphical display of the problems in a causal manner. The roots of the trees are the causes of the other problems and in the center, there is the main problem, whereas the upper branches display the effects of the main and the root problems. Because of the complex logical processes involved, this activity can take one to several hours. The students may exclude some problem branches and focus on the ones that are really important for them and can be solved through their direct implication. After narrowing down the problem tree, the students will convert the main problem into a project goal by imagining and formulating the positive future situation provided the problem is virtually solved (Borovic, 2019). The next steps are inspired from Project Citizen. After geting in contact with the real world to search relevant information (by talking to citizens, experts, neighbors, and/or parents, by searching the world wide web, by consulting the media, etc.) about the problem and its sub-problems, the students will search and discuss alternative solutions for each problem and then propose their own solution. Since WISH PBL is a learning method for students, it is not so much focused on designing a logical framework matrix (like MAPA) or a perfect advocacy plan (like Project Citizen). Its goal is to have a good structured plan for carrying out the project activities. Each project activity is a solution to one of the sub problems organized by students in logical trees. In the next step, the student team will present the project ideas (using presentations, posters, the world wide web, blogs, and social-media) to their peers or to community members in order to gain support and help. The major step of this method is the implementation of the project by carrying out the activities they have carefully planned. Learning is a byproduct of the activity (learning by doing) and is amplified by the next step: reflection. Reflection is both "individual insight" and whole group discussions about the planning and implementation of the project and the related experiences. Learning will result from a reflection on these experiences carried out both individually and in participative reflection groups (Borovic, 2019). 


\section{The research methodology}

\subsection{The experimental design}

Since the participant schools enrolled willingly in using WHISH PBL in their teaching and learning activities, including them in their formal and non-formal curriculum, we chose a quasi-experimental design with similar natural groups and pretest (Cristea, 2006). The participants from both the control and experimental groups were selected from several student classes of each school considering their similarity as the selection criterion. After the administration of the pretest, the similar student classes were split in an experimental group and a control group. Student classes that were very different from the general average profile were excluded from the experiment.

The instruments were applied to more than 300 students, but the sample consisted of the 226 teenage students (16-18 years) that offered valid answers. The students participated in an almost equal number from each high school: Colegiul Na ional Bănă ean Timişoara - 34.8\%, Colegiul Tehnic Energetic ,Regele Ferdinand I" Timişoara - 37.1\% and Liceul Pedagogic „Carmen Sylva” Timişoara - 28.1\%. To ensure that the data can be easier generalized, high schools with different profiles were picked out: theoretical, vocational and technical.

The gender distribution in the sample is shown in Figure no.1.

The pretest was applied during the first week of March 2018 and the posttest from $20^{\text {th }}$ of May to $15^{\text {th }}$ of June 2018. The WHISH PBL method (the independent variable) was applied during March - May 2018. To ensure uniformity of the experimental treatment, we organized WHISH PBL training workshops at the West University of Timişoara for all the involved teachers. 


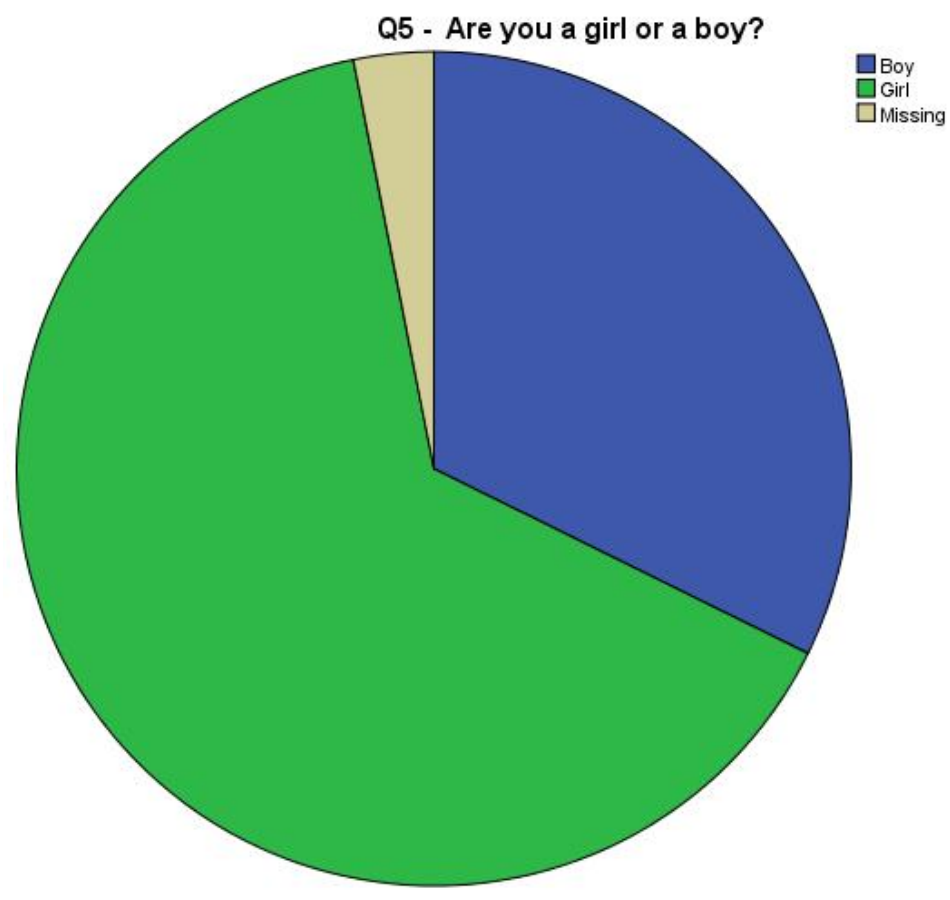

Figure no. 1. Distribution of student sample by gender

2.1. The instruments used in the quantitative research

The main instrument for the research was a posttest questionnaire containing 7 blocks of 4-point Likert scales. The values used in the scale were: 4: strongly agree, 3 : agree, 2: disagree, 1: strongly disagree. Most of the items used in the Likert scales are from IEA Civic Education Instrument and have been released for use in research (Schulz \& Sibberns, 2001). This makes data compatible with different studies worldwide. Since the object of this research was not civic education and citizenship, the items related to knowledge in this area where not included. As the Erasmus project dealt with social inclusion of disabled people, migrants, women, and LGBT, the questionnaire mainly focused on attitudes concerning social inclusion and towards disadvantaged groups, but also on some important $21^{\text {st }}$ Century Skills. The Likert scales with the questions for social inclusion and $21^{\text {st }}$ 
Century Skills were prepared and adapted by the Turkish project team (Ozmantar, 2019). The students were also asked about the name of their project and how they picked the main problem. There were also several demographical questions included to identify the schools, age, gender, and the level of participation in WHISH PBL projects.

The pretest applied in March 2018 insured that the experimental and the control groups of students were similar. The 21 questions were mostly demographical (some repeating the demographical questions from the posttest), but also about membership of vulnerable groups, organizations or volunteer groups; education of parents; number of family members; time spent with peers on Internet and social media; average grade, years of desired future education and other.

Both instruments were digitally applied in the selected schools using the online questionnaire tool Question Pro. The tests were applied with the help of laptop computers and smartphones in the classroom under the teacher's supervision. The data were exported from the Question Pro portal to SPSS version 20, where all statistical tests were carried out.

\subsection{Validity and reliability of the questionnaire}

To measure the reliability, or the internal consistency of the questionnaire, the Cronbach alpha test was used. The test analyses "if multiple-question Likert scale surveys are reliable" (Cronbach's Alpha: Simple Definition, Use and Interpretation, 2019). If alpha $=0.95$, we have a high degree of consistency that is used in clinical trials (Bland \& Altma, 1997). If a low alpha results from poor correlation between the items used, then Tavakol and Dennick (2011) suggest that the questionnaire should be revised or not used anymore.

The study participants which were divided into a control group and an experimental group were tested twice, once before and once after the experiment. The reliability of the instruments used in this study is as follows: the test shows that the instrument used is very highly reliable for 6 item blocks having an internal consistency level used in clinical trials and is reliable for the first question block. The detailed results also show good correlations between the indicators used in all question. 
Table no. 1. Reliability Statistics

\begin{tabular}{|c|c|c|c|c|}
\hline & $\begin{array}{c}\text { Number of valid } \\
\text { cases (from 269 } \\
\text { participants in } \\
\text { the survey) }\end{array}$ & $\begin{array}{c}\text { Cronbach's } \\
\text { Alpha }\end{array}$ & $\begin{array}{c}\text { Cronbach's } \\
\text { Alpha Based on } \\
\text { Standardized } \\
\text { Items }\end{array}$ & N of Items \\
\hline Q11 & 210 &, 872 &, 879 & 6 \\
\hline Q12 & 108 &, 978 &, 979 & 14 \\
\hline Q13 & 133 &, 971 &, 971 & 8 \\
\hline Q14 & 93 &, 993 &, 993 & 15 \\
\hline Q15 & 196 &, 977 &, 977 & 7 \\
\hline Q16 & 196 &, 980 &, 980 & 7 \\
\hline Q17 & 172 &, 993 &, 993 & 16 \\
\hline
\end{tabular}

\section{Research Results}

\subsection{Implementation of WHISH PBL}

During the implementation of the WHISH, the students in the pilot schools carried out four projects:

1. Bullying? Be smart, don't start! - the goal was to raise students' awareness about bullying in schools to prevent it and to give support to the victims.

2. Together with Julien - an awareness raising, fundraising and blood donation project for Julien, a boy with Down syndrome and kidney failure.

3. The Energy of a New Generation - awareness raising and volunteer activities to improve the image of vocational schools in the local community and to support school-leavers in finding jobs.

4. Two Times Two for New Ideas intended to help primary education children to understand historical text using "out of the box" activities.

More than $61 \%$ of the students chose the project problems by themselves, while a percentage of $33 \%$ confirmed the teacher involvement to a certain extent. Only $6 \%$ of them said that the teacher proposed the problem. From this point of view, the methodology was applied correctly. 


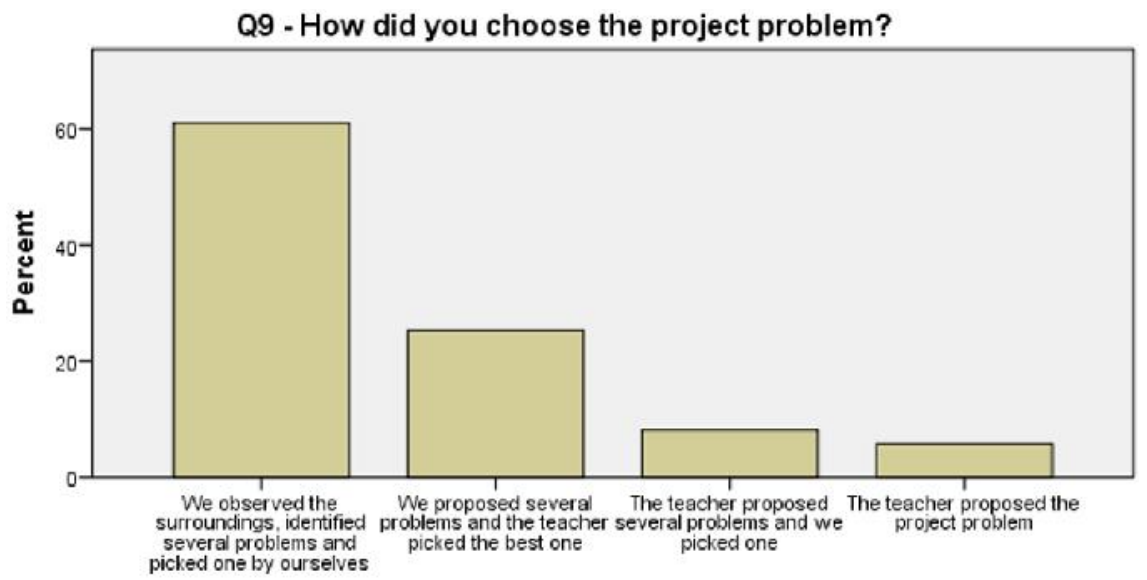

Figure no.2. Distribution of the experimental group students according to their choosing of project problems

Most of the projects $(80 \%)$ were large scale projects involving the whole class of students, but some projects were carried out with smaller teams.

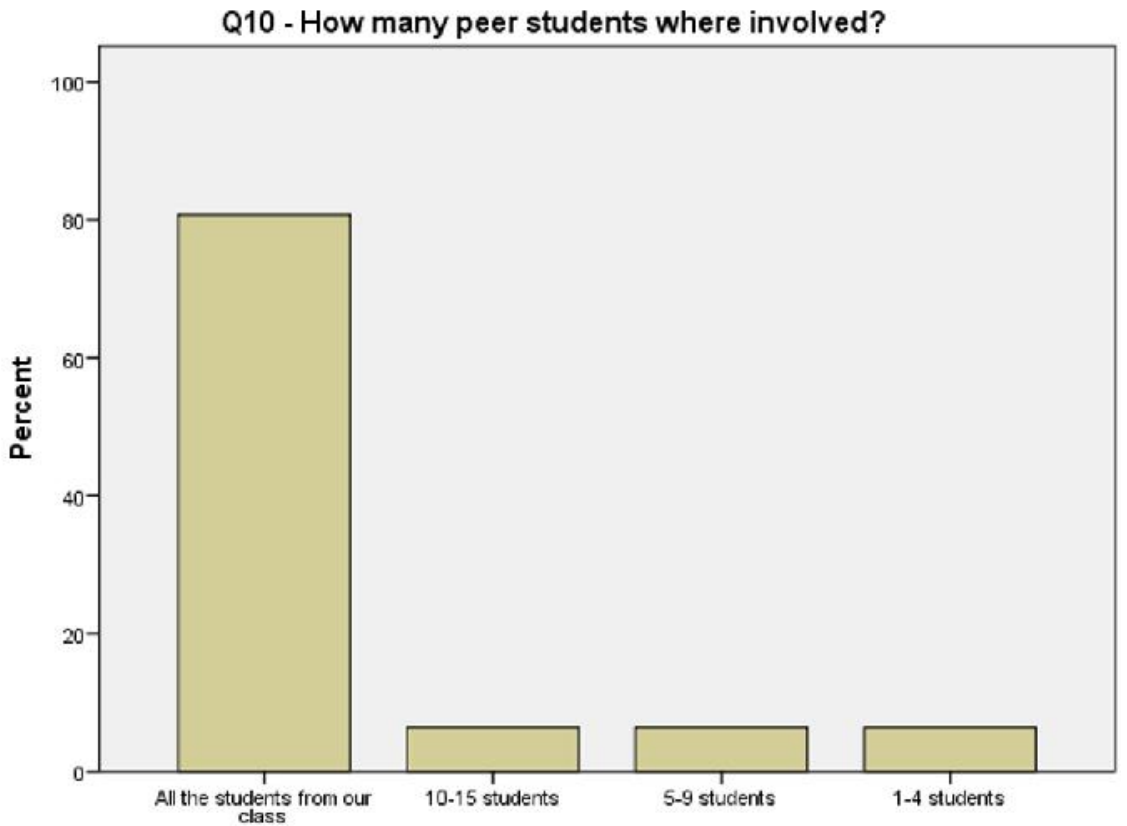

Figure no. 3. Size of the student project teams 


\subsection{Independent sample test}

The research employed 73 dependent variables. For 30 of them, significant changes in the experimental group were caused by the independent variable (WISH PBL), while for the remaining 43 variables, there was no significant difference between the experimental and the control groups.

\subsubsection{Perceived opportunities for members of discriminated groups}

The question block (Q11) deals with the opportunities of members belonging to groups that are subject to discrimination and/or do not benefit of equal opportunities in society.

Question: Q11 - F1 Children who are members of certain ethnic groups (immigrant groups, national groups, racial groups) have fewer opportunities than other children to get a (good) secondary (high school) education in this country. There was a significant difference in the scores for the experimental group $(\mathrm{M}=2,01, \mathrm{SD}=0,962)$ and the control group $(\mathrm{M}=2,26$, $\mathrm{SD}=0,802) ; \mathrm{t}(215)=-2,012, \mathrm{p}=0,045$. This suggests that participating in WHISH PBL makes the student aware that in Romania the minorities (as described in the question) are positively discriminated and they do not have reduced chances of quality education. For example, Roma students benefit of additionally places for study in schools and universities and there are schools for almost all national groups (schools in German, Hungarian, Serbian mother-tongue)

Question: Q11 - F2 Girls have fewer opportunities than boys to get a (good) secondary (high school) education in this country. There was a significant difference in the scores for the experimental group $(\mathrm{M}=1,57, \mathrm{SD}=0,711)$ and the control group $(\mathrm{M}=1,76, \mathrm{SD}=0,431) ; \mathrm{t}(218)=-2,302, \mathrm{p}=0,022$. Involvement in WHISH PBL, making girls and boys to act together, reduces the belief that girls have fewer opportunities of quality education. Statistics from the Ministry of Education (2016) also shows that, in the Romanian educational system, the students' average participation for all ages was 78,3\% for girls and $75 \%$ for boys. 
Question: Q11 - F3 Children from poor families have fewer opportunities than others to get a (good) secondary (high school) education in this country. There was a significant difference in the scores for the experimental group $(\mathrm{M}=2,33, \mathrm{SD}=1,245)$ and the control group $(\mathrm{M}=0,91, \mathrm{SD}=1,412)$; $\mathrm{t}(214)=7,786, \mathrm{p}=0,000$.

Question: Q11 - F4 Children who live in rural (farming) areas have fewer opportunities than others to get a (good) secondary (high school) education in this country. There was a significant difference in the scores for the experimental group $(\mathrm{M}=2,13, \mathrm{SD}=1,152)$ and the control group $(\mathrm{M}=0,79$, $\mathrm{SD}=1,269) ; \mathrm{t}(215)=8,141, \mathrm{p}=0,000$.

Involvement in WHISH PBL highly increases the students' agreement with the assertion (and the fact) that poverty and/or living in rural areas reduces access to quality high school education.

Question: Q11 - F6 Women have fewer opportunities than men to get good jobs in this country. There was a significant difference in the scores for the experimental group $(\mathrm{M}=1,87, \mathrm{SD}=0,903)$ and the control group $(\mathrm{M}=1,52$, $\mathrm{SD}=0,697) ; \mathrm{t}(200)=3,021, \mathrm{p}=0,003$. This shows that the students participating in project-based learning are more likely to agree with the fact that the women's chances to get a job are much less than men's.

Project Based Learning (PBL) makes students more aware of the opportunities that minorities or traditionally disadvantaged groups have in Romania. Since PBL requires to spend a lot of time researching several areas of interest and seeking information, the students from the experimental group are better informed about the real opportunities of several groups.

3.2.2. Opportunities which the members of certain groups (discriminated or disadvantaged ones) should have (Q12)

Question: Q12 - G1 Women should run for public office (a seat in the legislature) and take part in the government just as men do. There was a significant difference in the scores for the experimental group $(\mathrm{M}=2,82$, $\mathrm{SD}=0,954)$ and the control group $(\mathrm{M}=2,55, \mathrm{SD}=0,982) ; \mathrm{t}(208)=2,031, \mathrm{p}=0,044$. 
Participation of students in WHISH PBL increases their support for women participation in government.

Question: Q12 - G2 All ethnic (racial or national) groups should have equal chances to get a good education in this country. There was a significant difference in the scores for the experimental group $(\mathrm{M}=3,23, \mathrm{SD}=0,980)$ and the control group $(\mathrm{M}=2,44, \mathrm{SD}=1,043) ; \mathrm{t}(216)=5,788, \mathrm{p}=0,000$. Being an active part of WHISH PBL projects highly increases students' support for all ethnic groups to get equal access to quality education.

Question: Q12 - G4 Women should have the same rights as men in every way. There was a significant difference in the scores for the experimental group $(M=3,13, S D=1,112)$ and the control group $(M=2,29, S D=1,219)$; $\mathrm{t}(175)=5,062, \mathrm{p}=0,000$. Involvement in WHISH PBL highly increases the students' agreement with the equality of rights for women and men. Dealing with forms of discrimination and being engaged in reducing them makes students defend the same rights for women (who traditionally were discriminated) as for men.

Question: Q12 - G6 Women should stay out of politics. There was a significant difference in the scores for the experimental group $(M=1,99$, $\mathrm{SD}=1,021)$ and the control group $(\mathrm{M}=2,97, \mathrm{SD}=1,102) ; \mathrm{t}(206)=-6,584$, $\mathrm{p}=0,000$. The results for question $\mathrm{G6}$ are coherent with the results for question G1 and G4. Students that were involved in Project Based Learning tended to disagree much more than their uninvolved peers about the idea that women should stay out of politics. By means of PBL, students provide a qualified form of civic participation where girls and boys work together. This highly changes their view on women participation in politics and consequently they reject statements like the one from question G6.

Question: Q12 - G9 When jobs are scarce, men (should) have more rights to a job than women. There was a significant difference in the scores for the experimental group $(\mathrm{M}=2,03, \mathrm{SD}=1,058)$ and the control group $(\mathrm{M}=2,76$, $\mathrm{SD}=1,161) ; \mathrm{t}(203)=-4,705, \mathrm{p}=0,000$. Supporting the equality of rights between women and men, the students involved in the WHISH PBL project are against positive discrimination (under circumstances with a high unemployment rate) for men regarding the right to have a job. These 
statements implicitly question the role of women in society. The involvement in PBL promotes a positive attitude concerning the equality of roles for all genders in society.

Question: Q12 - G10 Members of anti-democratic groups (groups that are against democracy) should be prohibited from running in an election for political office. There was a significant difference in the scores for the experimental group $(\mathrm{M}=2,46, \mathrm{SD}=1,040)$ and the control group $(\mathrm{M}=1,81$, $\mathrm{SD}=1,030) ; \mathrm{t}(141)=3,810, \mathrm{p}=0,000$. Students involved in PBL are more likely to defend the core values of democracy by agreeing to prohibit participation of anti-democratic groups in the political life.

Question: Q12 - G12 Members of all ethnic (racial or national) groups should be encouraged to run in elections for political office. There was a significant difference in the scores for the experimental group $(\mathrm{M}=2,65$, $\mathrm{SD}=0,983)$ and the control group $(\mathrm{M}=3,32, \mathrm{SD}=0,883) ; \mathrm{t}(200)=-5,009$, $\mathrm{p}=0,000$. The result for this question is not coherent with the other results in these question blocks. Although other indicators are positively influenced through PBL, it seems that this is not true for the participation of all ethnic groups to run in elections for political office.

\subsubsection{Questions regarding the positive attitudes toward immigrants}

Immigrants are an important group of people who tend to be disadvantaged. This is why several questions were asked about the attitude towards immigrants and their families.

Question: Q13 - H1 Immigrants should have the opportunity (option) to keep (continue speaking) their own language. There was a significant difference in the scores for the experimental group $(\mathrm{M}=2,83, \mathrm{SD}=0,995)$ and the control group $(\mathrm{M}=3,22, \mathrm{SD}=1,083) ; \mathrm{t}(199)=-2,616, \mathrm{p}=0,010$. Students involved in PBL have a less positive attitude regarding the use of the immigrants' own language. This was not enforced by the projects, is not coherent with other questions related to immigrants, so the results might be circumstantial. 
Question: Q13 - H2 Immigrants' children should have the same opportunities for education that other children in the country have. There was a significant difference in the scores for the experimental group $(\mathrm{M}=3,15, \mathrm{SD}=0,908)$ and the control group $(\mathrm{M}=2,82, \mathrm{SD}=1,073) ; \mathrm{t}(188)=2,292, \mathrm{p}=0,023$. Involvement in WHISH PBL highly increases the students' agreement with the equality of opportunity for education of immigrant and other children in Romania. This underlines the fact that one effect of PBL on students is to consider peers with different backgrounds to be their equals.

Question: Q13 - H3 Immigrants who lived in a country for several years should have the opportunity to vote in elections. There was a significant difference in the scores for the experimental group $(\mathrm{M}=2,44, \mathrm{SD}=0,937)$ and the control group $(\mathrm{M}=2,06, \mathrm{SD}=1,063) ; \mathrm{t}(187)=2,629, \mathrm{p}=0,009$. Thanks to participation in WHISH PBL, the students are more likely to give immigrants the opportunity to vote in elections.

Question: Q13 - H6 Immigrants should be forbidden to engage in political activity. There was a significant difference in the scores for the experimental group $(\mathrm{M}=2,46, \mathrm{SD}=0,971)$ and the control group $(\mathrm{M}=2,94, \mathrm{SD}=1,084)$; $\mathrm{t}(188)=-3,243, \mathrm{p}=0,001$. Students involved in Project Based Learning are more likely to disagree that engagement in political activities for immigrants should be forbidden.

Question: Q13 - H8 All countries should accept refugees who are trying to escape from wars or political persecution in other countries. There was a significant difference in the scores for the experimental group ( $M=2,95$, $\mathrm{SD}=0,951)$ and the control group $(\mathrm{M}=2,54, \mathrm{SD}=1,107) ; \mathrm{t}(157)=2,677$, $\mathrm{p}=0,008$. Thanks to the participation in WHISH PBL, the students are more likely to accept refugees trying to seek political asylum.

\subsubsection{Questions concerning social inclusion}

Question: Q14 - A2 I am aware of social inclusion issues. There was a significant difference in the scores for the experimental group $(\mathrm{M}=2,68$, $\mathrm{SD}=1,083)$ and the control group $(\mathrm{M}=2,28, \mathrm{SD}=1,165) ; \mathrm{t}(171)=2,273$, $\mathrm{p}=0,024$. Due to participation in WHISH PBL, the students are more aware 
of social inclusion issues. This can be explained by the fact that a major objective of the WHISH project was to raise awareness on social inclusion.

Question: Q14 - A3 I am aware of the difficulties/ problems that the disadvantaged groups experience. There was a significant difference in the scores for the experimental group $(\mathrm{M}=2,84, \mathrm{SD}=0,938)$ and the control group $(\mathrm{M}=2,37, \mathrm{SD}=1,198) ; \mathrm{t}(133)=2,928, \mathrm{p}=0,004$.

Question: Q14 - A8 I can recognize disadvantaged people living in the same environment with me. There was a significant difference in the scores for the experimental group $(\mathrm{M}=2,85, \mathrm{SD}=1,065)$ and the control group $(\mathrm{M}=2,43, \mathrm{SD}=1,311) ; \mathrm{t}(114)=2,211, \mathrm{p}=0,029$.

Question: Q14 - A9 I pay attention to the disadvantaged people living in our society. There was a significant difference in the scores for the experimental group $(\mathrm{M}=2,70, \mathrm{SD}=1,114)$ and the control group $(\mathrm{M}=2,22$, $\mathrm{SD}=1,133) ; \mathrm{t}(183)=2,829, \mathrm{p}=0,005$.

Participating in student designed project-based learning experiences increases the students' awareness of not only recognizing disadvantaged groups, but also identifying their specific difficulties and problems, which makes these groups of people less invisible (Question A3, A8, A9).

Question: Q14 - A5 I follow (share, re-tweet, like) social media related to disadvantaged groups. There was a significant difference in the scores for the experimental group $(\mathrm{M}=2,42, \mathrm{SD}=0,975)$ and the control group $(\mathrm{M}=2,03$, $\mathrm{SD}=1,189) ; \mathrm{t}(160)=2,221, \mathrm{p}=0,028$. As a consequence of being more receptive to the people from disadvantaged groups and their problems, the students involved in PBL are more likely to share these experiences in the social media.

\subsubsection{Questions concerning students' participation in school life}

Results show that students' participation in school life significantly improves through involvement in WISH PBL. This can be illustrated through the following indicators: 
Question: Q15 - J1 Electing student representatives to suggest changes in how the school is run (how to solve school problems) makes schools better. There was a significant difference in the scores for the experimental group $(\mathrm{M}=2,78, \mathrm{SD}=1,087)$ and the control group $(\mathrm{M}=2,29, \mathrm{SD}=1,168)$; $\mathrm{t}(188)=2,918, \mathrm{p}=0,004$. Involvement in WISH PBL raises students' trust in the importance of electing student representatives to solve school problems. This question includes two aspects: 1 . The importance of electing student representatives and 2 . The confidence that the students' representatives can contribute to solving school problems and making schools better.

Question: Q15 - J2 Lots of positive changes happen in this school when students work together. There was a significant difference in the scores for the experimental group $(\mathrm{M}=3,17, \mathrm{SD}=1,079)$ and the control group $(\mathrm{M}=2,78$, $\mathrm{SD}=1,182) ; \mathrm{t}(204)=2,442, \mathrm{p}=0,015$. Participating in group work during the implementation of WHISH PBL increases students' belief in the positive changes that may happen in school through team work.

Question: Q15 - J4 If members of my class felt they were unfairly treated, I would be willing to go with them to speak to the teacher. There was a significant difference in the scores for the experimental group ( $M=2,77$, $\mathrm{SD}=1,106)$ and the control group $(\mathrm{M}=1,98, \mathrm{SD}=1,151) ; \mathrm{t}(201)=4,950$, $\mathrm{p}=0,000$. Significantly more students from the experimental group would support their unfairly treated peer (would join them to speak to the teacher). Team project-based learning activities increase the sense of justice and the need of mutual support of students.

\subsubsection{Questions concerning school curriculum and learning}

Question: Q16 - K6 In school I have learned to be concerned about what happens in other countries. There was a significant difference in the scores for the experimental group $(\mathrm{M}=2,53, \mathrm{SD}=1,107)$ and the control group $(\mathrm{M}=2,94, \mathrm{SD}=1,200) ; \mathrm{t}(203)=-2,583, \mathrm{p}=0,010$. Thanks to participation in WHISH PBL, the students have more opportunities to interact with students from other countries. This is why students from the experimental group are more concerned about events, social and political life from other countries. 
For the other items in this group there is no significant difference between the results for the experimental and the control group.

\subsubsection{Questions concerning $21^{\text {th }}$ Century Skills}

The $21^{\text {th }}$ Century Skills were checked through direct questions, three of which had a statistically significant increase as follows:

Question: Q17 - B1 I can use digital tools to locate information (digital tools: online books and articles, Internet searches, online discussions, gathering information from websites, or online databases). There was a significant difference in the scores for the experimental group $(M=2,98$, $\mathrm{SD}=1,163)$ and the control group $(\mathrm{M}=2,63, \mathrm{SD}=1,295) ; \mathrm{t}(172)=1,974$, $\mathrm{p}=0,050$. Searching information with digital tools is a very important skill in developing student projects. This is why this skill is used (and exercised) in several ways in WHISH PBL: for finding problems in the community, for finding information about these problems and for seeking solutions. On the other hand, digital tools are used in finding support for the project and sharing the project to the community. This is why the skill is significantly improved for the students involved in PBL.

Question: Q17 - B3 I can take responsibility to accomplish a goal on a group project. There was a significant difference in the scores for the experimental group $(\mathrm{M}=2,93, \mathrm{SD}=1,231)$ and the control group $(\mathrm{M}=2,49$, $\mathrm{SD}=1,253) ; \mathrm{t}(198)=2,445, \mathrm{p}=0,015$. WISH PBL enforces taking responsibility in the project by having certain tasks and roles for each student. This brings increased responsibility in a group project for the students involved.

Question: Q17 - B4 I can collaborate with my peers to achieve a goal on a project. There was a significant difference in the scores for the experimental group $(\mathrm{M}=3,00, \mathrm{SD}=1,171)$ and the control group $(\mathrm{M}=2,49, \mathrm{SD}=1,285)$; $\mathrm{t}(204)=2,963, \mathrm{p}=0,003$. The WISH PBL requires collaboration and team work to accomplish the project goal. This is why the skills for collaboration are highly improved through Project Based Learning. 


\section{Conclusion}

Although the questionnaire used mostly questions from dedicated citizenship education research, the questions are in fact also useful for researching attitudes towards social inclusion and $21^{\text {st }}$ Century Skills.

WHISH PBL is not subject bound and can be applied in a transdisciplinary and non-formal approach. In Romania, the projects did not have the requirement to be about social inclusion. Social inclusion was considered an effect of the project as a whole and was not linked to a specific problematic area (like disabled people, immigrants or the LGBT minority) like in Catalonia, Italy, Slovakia and Turkey. Yet, WHISH PBL increased statistically significant several positive attitudes related to migrants, minorities, women, people with different political views. On the other hand, positive results were found regarding the skills to cooperate, to seek information, to elaborate and implement projects and so on. These are important $21^{\text {st }}$ Century Skills and can be found in most of the available frameworks.

Not all the skills included in the questionnaire were influenced trough WHISH PBL. We cannot hope to solve all the education problems with one methodology, but we recommend it to be used in transdisciplinary and/or non-formal contexts as an important means of developing skills and social inclusion.

It is also crucial for the teachers to enroll in a WHISH PBL training, or at least to study carefully the methodological guide and some sample projects. Too much involvement from the teacher or skipping some basic steps in project planning may change the methodology completely and may not produce the expected positive results.

\section{Acknowledgements:}

The author would like to thank Dr. Maria Niculescu, Dr. Dana Gavreliuc and Dr. Marius Crişan, members of the Romanian WISH project team, for the implementation of the project and the support for the research activities. 


\section{References}

- Bland, J. M., \& Altma, D. G. (1997). Statistics notes. Cronbach's alpha. British Medical Journal, 314(7080), 572. https://doi.org/10.1136/bmj.314.7080.572

- Borovic, D. (2019). Project Based Learning in 11 Easy Steps. Retrieved from http://www.wish-project.eu/wp-content/uploads/2019/06/Project-BasedLearning-Guide-v2.pdf

- Cristea, S. (2006). Curriculum Pedagogic. Bucureşti: Editura Didactică şi Pedagogică.

- Glen, S. (2014). Cronbach's Alpha: Simple Definition, Use and Interpretation. Retrieved from https://www.statisticshowto.datasciencecentral.com/

- Ministerul Educa iei Na ionale. (2016). Raport privind starea învă ământului preuniversitar din România. Retrieved from https://www.edu.ro/sites/default/ files/_fi\%C8\%99iere/Minister/2017/transparenta/Stare\%20preuniv\%20 2016.pdf

- Ozmantar, M., F. (2019). WISH: Work for an Inclusive School Heritage Project. Final Report.

- Schiefer, U., \& Döbel, R. (2001). MAPA - Project. A Practical Guide to Integrated Project Planning and Evaluation. Budapest: OSI-IEP Publications.

- Schulz, W., \& Sibberns H. (2001). IEA Civic Education Study Technical Report. Amsterdam: International Association for the Evaluation of Educational Achievement (IEA).

- Tavakol, M., \& Dennick, R. (2011). Making sense of Cronbach's alpha. International Journal of Medical Education, 2, 53-55. https://doi.org/10.5116/ ijme.4dfb.8dfd

- Rock, B. (2017). What Is Project Citizen and How Does It Relate to Civics? Retrieved from http://civiceducator.org/what-is-project-citizen-civics-education/

The online version of this article can be found at: http://revped.ise.ro/category/2019-en/

\section{$( c c ) \longdiv { B Y - N C - B A }$}

This work is licensed under the Creative Commons Attribution-NonCommercial-ShareAlike 4.0 International License.

To view a copy of this license, visit http://creativecommons.org/licenses/by-nc-sa/4.0/ or send a letter to Creative Commons, PO Box 1866, Mountain View, CA 94042, USA.
Versiunea online a acestui articol poate fi găsită la: http://revped.ise.ro/category/2019-ro/

\section{$(C C))(B-N C-s a$}

Această lucrare este licen iată sub Creative Commons Attribution-NonCommercial-ShareAlike 4.0 International License.

Pentru a vedea o copie a acestei licen e, vizita $i$ http://creativecommons.org/licenses/by-nc-sa/4.0/ sau trimite i o scrisoare către Creative Commons, PO Box 1866, Mountain View, CA 94042, SUA. 